\title{
Thymidylate synthase and methylenetetrahydrofolate reductase gene polymorphisms: relationships with 5-fluorouracil sensitivity
}

\author{
M-C Etienne', K IIc', J-L Formento', P Laurent-Puig', P Formento', S Cheradame', J-L Fischel' and \\ G Milano ${ }^{1,2, *}$
}

'Oncopharmacology Unit, Centre Antoine Lacassagne, 33 Avenue de Valombrose, 06189 Nice Cedex 2, France; ${ }^{2}$ Unité de Toxicologie Moléculaire, INSERM U490, 45 rue des Saints Pères, 75270 Paris Cedex 06, France

The relationship of thymidylate synthase (TS) and methylenetetrahydrofolate reductase (MTHFR) gene polymorphisms on 5fluorouracil (FU) sensitivity was tested on 19 human cancer cell lines (head and neck, breast, digestive tract) in the absence and presence of folinic acid (FA) supplementation. Thymidylate synthase polymorphisms in the $5^{\prime}$ promoter region (double or triple tandem repeats) and 3' untranslated region (6-bp deletion) were analysed by PCR. The C677T and AI298C MTHFR polymorphisms were determined by melting curve analyses (LightCycler). Thymidylate synthase activity and intracellular concentration of the reduced folate 5-10 methylenetetrahydrofolate $\left(\mathrm{CH}_{2} \mathrm{FH}_{4}\right)$ were measured (biochemical assays). Thymidylate synthase activity was significantly different according to 5' TS genotype, heterozygous cell lines (2R/3R) exhibiting higher TS activities than homozygous ones $(P=0.05)$. However, whether in the absence or presence of FA, FU sensitivity was not statistically associated with either $5^{\prime}$ or $3^{\prime}$ TS polymorphism. Basal $\mathrm{CH}_{2} \mathrm{FH}_{4}$ cellular concentrations were lowest in $\mathrm{C} 677 \mathrm{~T}$ homozygous wild-type (wt) (C/C) cell lines. FU sensitivity was not linked to $\mathrm{C} 677 \mathrm{~T}$ polymorphism. In contrast, there was a marked trend for a greater FU efficacy in mutated Al298C variants $(C / C+A / C)$ as compared to wt homozygous cell lines $(A / A)(P=0.055$ and 0.085 without and with $F A$ supplementation, respectively). These results suggest for the first time a potential role of AI298C MTHFR polymorphism on fluoropyrimidine sensitivity.

British Journal of Cancer (2004) 90, 526-534. doi:I0.I038/sj.bjc.660I523 www.bjcancer.com (c) 2004 Cancer Research UK

Keywords: thymidylate synthase; methylenetetrahydrofolate reductase; pharmacogenetics; gene polymorphism; 5-fluorouracil; fluoropyrimidine

5-Fluorouracil (FU) and fluoropyrimidine prodrugs remain the drugs of choice for the treatment of colorectal (Wils et al, 2001), breast (Fumoleau et al, 2003) and head and neck cancers (Posner et al, 2000). The conversion of $\mathrm{FU}$ into fluorodeoxyuridine monophosphate (FdUMP) leads to the inhibition of thymidylate synthase (TS, EC 2.1.1.45, the key enzyme of de novo deoxythymidine $5^{\prime}$-monophosphate synthesis, Figure 1) and subsequent DNA synthesis arrest. The presence of FdUMP induces the formation of an inactive ternary complex between TS, FdUMP, and the methyl donor-reduced folate 5-10 methylenetetrahydrofolate $\left(\mathrm{CH}_{2} \mathrm{FH}_{4}\right)$. Experimental studies have clearly established that the stabilisation of the ternary complex, and thus optimal TS inhibition, requires elevated cellular concentrations of $\mathrm{CH}_{2} \mathrm{FH}_{4}$ (Danenberg and Danenberg, 1978; Houghton et al, 1981; Rustum et al, 1987; Keyomarsi and Moran, 1988; Chéradame et al, 1997a). Accordingly, clinical studies have demonstrated higher antitumour efficacy when FU is associated with folinic acid (FA), a precursor of $\mathrm{CH}_{2} \mathrm{FH}_{4}$ (Petrelli et al, 1987; Poon et al, 1989; Doroshow et al, 1990; Piedbois et al, 1992; Jäger et al, 1996). We previously closely

* Correspondence: G Milano, Oncopharmacology Unit, Centre Antoine Lacassagne, 33 Avenue de Valombrose, 06189 Nice Cedex 2, France; E-mail: gerard.milano@nice.fnclcc.fr

Received I 4 July 2003; revised 16 October 2003; accepted 24 October 2003 studied the role of FA supplementation and $\mathrm{CH}_{2} \mathrm{FH}_{4}$ intratumoral concentration on FU efficacy in a panel of 14 human cell lines (Chéradame et al, 1997a). Moreover, in patients receiving cisplatin-FU chemotherapy, we previously supplied direct evidence of the role of intratumoral $\mathrm{CH}_{2} \mathrm{FH}_{4}$ on $\mathrm{FU}$ efficacy, with significantly lower tumoral $\mathrm{CH}_{2} \mathrm{FH}_{4}$ concentrations in nonresponding patients as compared to responding patients (Chéradame et al, 1997b).

The intracellular $\mathrm{CH}_{2} \mathrm{FH}_{4}$ concentration is mainly controlled by the methylenetetrahydrofolate reductase enzyme (MTHFR, EC 1.5.1.20), which irreversibly converts $\mathrm{CH}_{2} \mathrm{FH}_{4}$ into 5-methyltetrahydrofolate (Figure 1) (Scott and Weir, 1994). Methylenetetrahydrofolate reductase is located at a major metabolic crossroad, directing the folate pool towards remethylation of homocysteine to methionine (and subsequent DNA methylation) at the expense of DNA synthesis (Figure 1). Methylenetetrahydrofolate reductase gene is located on chromosome $1 \mathrm{p}$, and is subject to several polymorphisms (Rozen, 1996). Among them, the C677T (exon 4) and A1298C (exon 7) single-nucleotide polymorphisms (SNPs) are the two most commonly linked with altered phenotypes, both associated with lower enzyme activity (Frosst et al, 1995; Weisberg et al, 1998). The frequency of the mutated 677 TT genotype is around $10-15 \%$ in Caucasians, and only a few percent in AfroAmericans (Ueland et al, 2001). The $677 \mathrm{C}>\mathrm{T}$ mutation enhances the thermolability of the enzyme (Frosst et al, 1995). The mutated 
677 TT genotype is associated with elevated plasma homocysteine concentrations, as well as DNA hypomethylation that is involved in carcinogenesis processes. The influence of C677T polymorphism on disease risk is closely related to the nutritional folate status. In case of folate intake deficiency, 677 TT genotype is related to increased risk of congenital neural tube defect and to colorectal cancer (Ueland et al, 2001). The A1298C genotype has been less extensively studied (Van der Put et al, 1998; Weisberg et al, 1998) and the frequency of the mutated 1298 CC genotype reported in

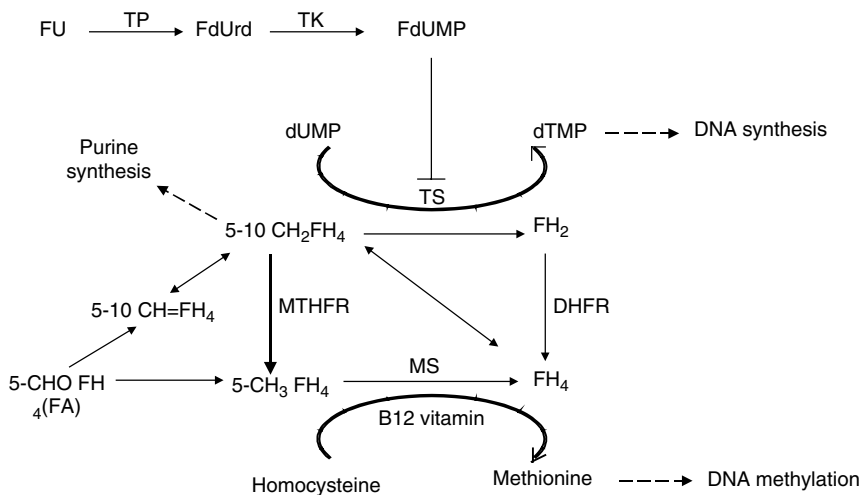

Figure I Folate metabolic pathways related to MTHFR and TS. 5- 10 $\mathrm{CH}=\mathrm{FH}_{4}, 5-10$ methenyltetrahydrofolate; 5- $10 \mathrm{CH}_{2} \mathrm{FH}_{4}$, 5-I0 methylenetetrahydrofolate; $5-\mathrm{CH}_{3} \mathrm{FH}_{4}$, 5-methyltetrahydrofolate; 5- $\mathrm{CHOFH}_{4}(\mathrm{FA})$, 5-formyltetrahydrofolate; DHFR, dihydrofolate reductase; dTMP, deoxythymidine 5'-monophosphate; dUMP, deoxyuridine 5'-monophosphate; FdUMP, 5-fluorodeoxyuridine 5'-monophosphate; FdUrd, 5-fluorodeoxyuridine; $\mathrm{FH}_{2}$, dihydrofolate; $\mathrm{FH}_{4}$, tetrahydrofolate; $\mathrm{FU}$, 5-fluorouracil; $\mathrm{MS}$, methionine synthase; MTHFR, 5-10 methylenetetrahydrofolate reductase; TK, thymidine kinase; TP, thymidine phosphorylase; TS, thymidylate synthase.
Japanese patients is around 3\% (Urano et al, 2002). Interestingly, Urano et al (2002) recently reported that the mutated 677 TT genotype was associated with greater methotrexate toxicity, whereas the mutated 1298 CC genotype was linked with better methotrexate efficacy. Since MTHFR enzymatic deficiency may theoretically favour thymidine synthesis via an increase of $\mathrm{CH}_{2} \mathrm{FH}_{4}$, one can hypothesise that tumours exhibiting mutated MTHFR genotypes linked to enzymatic deficiency may be more sensitive to FU cytotoxicity than wild-type (wt) MTHFR genotype tumours. Such a possible impact of MTHFR genotype may also affect normal host tissues. So far, the influence of C677T and A1298C polymorphisms on fluoropyrimidine sensitivity and/or toxicity remains unknown.

Numerous experimental and clinical studies have previously shown that elevated tumoral TS activity or expression is related to FU resistance (Beck et al, 1994; Peters et al, 2002). The TS gene is located on chromosome 18p. A genetic polymorphism has been reported in the $5^{\prime}$ regulatory region (cis-acting enhancer element) of the TS promoter that presents either double or triple tandem repeats of a $28 \mathrm{bp}$ sequence in Caucasian and Asian populations (Horie et al, 1995; Marsh et al, 1999). In an expression assay, Horie et al (1995) first reported that expression of the gene with triple repeat was higher than that of the gene with double repeat. Clinical studies have reported that triple repeat homozygous tumors (3R/ 3R) exhibit either higher TS mRNA or TS protein levels as compared to double repeat homozygous (2R/2R) (Kawakami et al, 2001b; Pullarkat et al, 2001). Recent clinical studies performed on small sets of patients have suggested that $5^{\prime}$ TS polymorphism may influence fluoropyrimidine sensitivity, with lower response rate in homozygous $3 \mathrm{R} / 3 \mathrm{R}$ patients as compared to others (Marsh et al, 2001; Pullarkat et al, 2001; Villafranca et al, 2001; Park et al, 2002). We recently analysed $5^{\prime}$ TS genotype on a large set of metastatic colorectal cancer patients receiving FU-based therapy and found similar response rates in $3 \mathrm{R} / 3 \mathrm{R}, 3 \mathrm{R} / 2 \mathrm{R}$ and $2 \mathrm{R} /$ $2 \mathrm{R}$ patients (Etienne et al, 2002). A second TS polymorphism

Table I Cell line characteristics and FU sensitivity (mean \pm s.e. from three separate experiments)

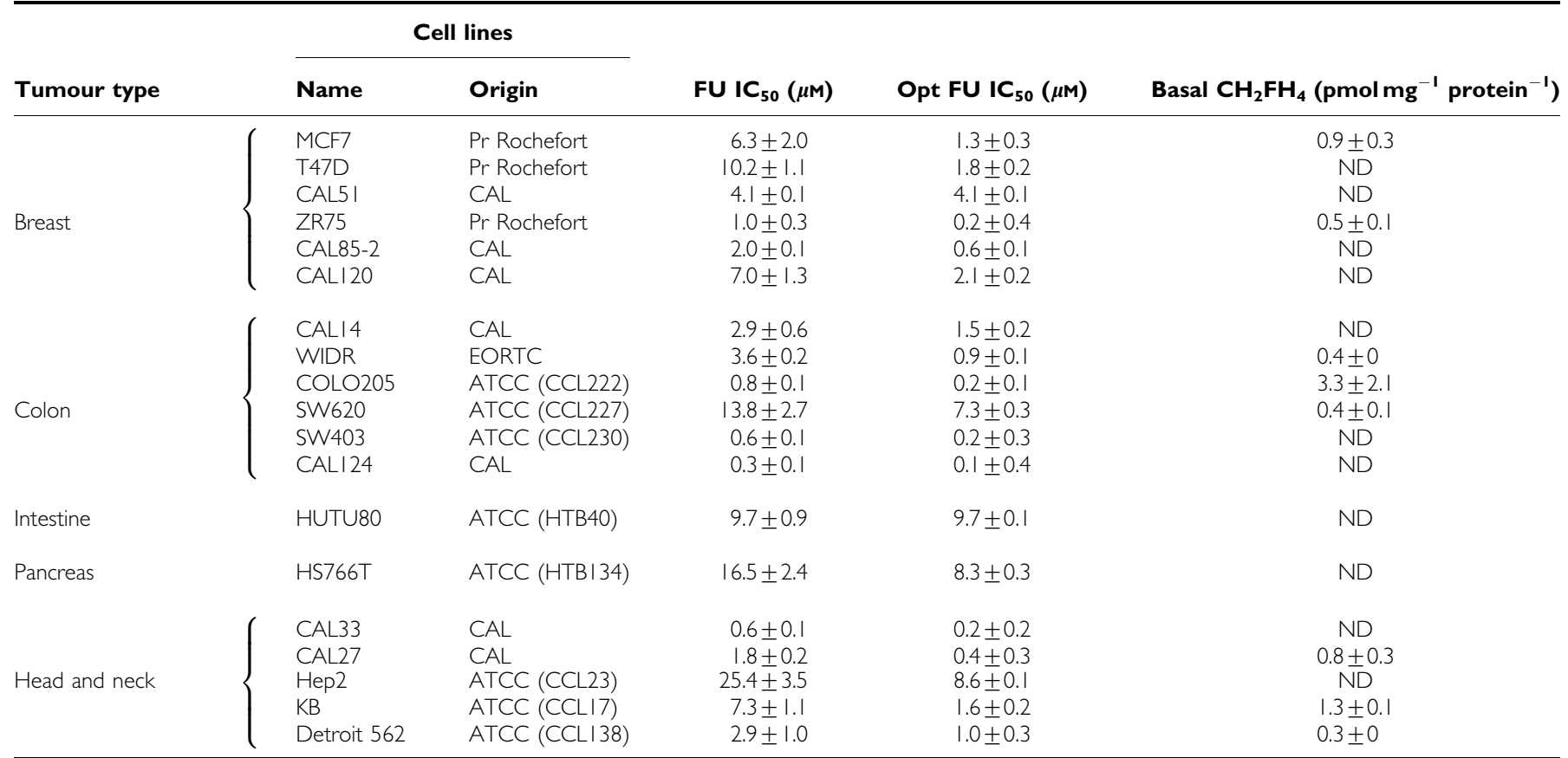

Opt FU IC $C_{50}=$ optimal FU IC 50 obtained with FA supplementation (see Material and Methods); ND = not detectable; $\mathrm{CH}_{2} \mathrm{FH}_{4}=$ methylenetetrahydrofolate. Cell line origins: CAL cell lines come from our institute; Pr Rochefort is from INSERM U I84, Montpellier, France; EORTC, European Organisation for Research and Treatment of Cancer; ATCC, American Type Culture Collection (Rockeville, MD, USA). 
consisting of a $6 \mathrm{bp}$ deletion at bp 1494 in the $3^{\prime}$ untranslated region has recently been reported (Ulrich et al, 2000). The deleted $3^{\prime}$ variant is associated with decreased TS mRNA levels in colorectal tumours (Ulrich et al, 2000). No study has been reported on the relationship between $3^{\prime}$ TS polymorphism and fluoropyrimidine sensitivity.

The purpose of the present study was to analyse the relationship between major TS and MTHFR polymorphisms on FU sensitivity. To this end, we investigated a large panel of 19 human cancer cell lines representative of fluoropyrimidine-treated tumours (digestive, breast, head and neck), and expressing spontaneous sensitivity to FU. Special attention was paid to the reduced folate status, and FU sensitivity was evaluated in the absence or presence of FA supplementation in order to take into account the different fluoropyrimidine-based protocols administered to patients. In addition to the possible relationships between studied polymorphisms and FU cytotoxicity, we analysed the relationship between TS activity and polymorphisms, as well as links between $\mathrm{CH}_{2} \mathrm{FH}_{4}$ basal concentrations and MTHFR polymorphisms.

\section{MATERIAL AND METHODS}

\section{Primers and probes}

Primers and probes were all synthesised by Proligos (Paris, France). For TS polymorphisms, forward and reverse primers were GTGGCTCCTGCGTTTCCCCC and GCTCCGAGCCGGCCACAGGCA, respectively, for $5^{\prime}$ TS polymorphism, and GACGAATGCAGAACACTTCT and AATCTGAGGGAGCTGAGTAAC, respectively, for $3^{\prime}$ TS polymorphism.

For MTHFR polymorphisms, anchor probes were labelled on the $3^{\prime}$ extremity with fluorescein. Mutated specific probes were labelled at the $5^{\prime}$ extremity with LC-Red-640 for C677T and LC-Red-705 for A1298C variants and were phosphorylated on their $3^{\prime}$ extremity to avoid extension by PCR.

Primers for C677T variants were: forward 5'-TGG CAG GTT ACC CCA AAG G-3'; reverse $5^{\prime}$-TGA TGC CCA TGT CGG TGC-3'. Labelled probes for C677T variants were: anchor $5^{\prime}$-TGA GGC TGA CCT GAA GCA CTT GAA GGA GAA GGT GTC T-fluo; $C$ variant (wild type) $5^{\prime}$-Red 640-CGG GAG CCG ATT TCA TCA T-3' phos; $T$ variant (mutated) $5^{\prime}$-Red 640-CGG GAG TCG ATT TCA TCA T-3' phos. Primers for A1298C variants were: forward $5^{\prime}$-CTT TGG GGA GCT GAA GGA CTA CTA C-3'; reverse 5'-CAC TTT GTG ACC ATT CCG GTT TG-3'. Labelled probes for A1298C variants were: anchor 5'-AAG GAG GAG CTG CTG AAG ATG TGG GGG GAG GAG CTfluo; $A$ variant (wild type) 5'-Red 705-ACC AGT GAA GAA AGT GTC TTT GA-3' phos; $C$ variant (mutated) 5'-Red 705-ACC AGT GCA GAA AGT GTC TTT GA-3' phos.

\section{Cell lines}

This study was conducted on a panel of 19 human cancer cell lines (six breast, seven digestive tract, five head and neck, one pancreas) expressing spontaneous sensitivity to $\mathrm{FU}$ (not previously exposed to $\mathrm{FU}$ ), with $\mathrm{IC}_{50}$ ranging from 0.3 to $25 \mu \mathrm{M}$ (Table 1). Cell doubling time ranged from 1.3 to 6.3 days (mean 2.7, median 2.2).

\section{Biochemical investigations}

Of the 19 cell line panel, 14 had been previously investigated for FU sensitivity with or without FA supplementation, intracellular reduced folate content, and TS activity (Chéradame et al, 1997a), as briefly described below. In order to match the physiological circulating folate concentration in humans, cells were grown in a folate-controlled medium for 10 days before experiments were started (folate-free DMEM medium supplemented with $40 \mathrm{~nm}$ of $d l$ - 5-methyltetrahydrofolate, $0.1 \mathrm{~mm}$ of $l$ - ascorbic acid for folate stabilisation, $10 \% \mathrm{FBS}, 2 \mathrm{~mm}$ glutamine, $50000 \mathrm{Ul}^{-1}$ penicillin and $80 \mu \mathrm{m}$ streptomycin) and all experiments have been subsequently performed in this folate-controlled medium.

Cytotoxicity experiments Cells were exposed for 5 days to various FU (14 concentrations ranging from 0.01 to $500 \mu \mathrm{M}$ ), FA (6 concentrations ranging from 0.01 to $300 \mu \mathrm{M}$ of pure l-FA) or $\mathrm{FU}+\mathrm{FA}$ concentrations (sextuplicates in 96-well microtitration plates). Growth inhibition was assessed by the MTT test (Carmichael et al, 1987) and the dose-effect curves were analysed on GraphPad software (ISI, USA).

Intracellular reduced folate measurement After 5days of growth $\left(175 \mathrm{~cm}^{2}\right.$ plates $)$, cells were harvested, washed three times in phosphate buffer saline at $+4^{\circ} \mathrm{C}$ and cell pellets containing approximately $50 \times 10^{6}$ cells were stored in liquid nitrogen. 5-10 Methylenetetrahydrofolate was measured on a $15000 \mathrm{~g}$ cytosol, as previously described (Chéradame et al, 1997a), based on the entrapment assay initially developed by Bunni et al (1988). This assay is based on the stoicheiometric formation of a stable ternary complex between $\mathrm{CH}_{2} \mathrm{FH}_{4}$, excess purified TS $(0.225 \mu \mathrm{M}$ final concentration), and excess ${ }^{3} \mathrm{H}$-FdUMP $(0.35 \mu \mathrm{M}$ final concentration). Recovery calculated from controls containing known $\mathrm{CH}_{2} \mathrm{FH}_{4}$ concentrations was $90 \%$ on average. Sensitivity limit was 0.3 pmol mg $\mathrm{m}^{-1}$ protein. Intra- and interassay reproducibility were 9.4 and $25.0 \%$, respectively.

Measurement of TS activity Thymidylate synthase activity was measured according to the tritium-release assay initially described by Spears and Gustavsson (1988) and modified by us (Etienne et al, 2002). Cells $\left(4 \times 10^{6}\right.$ cells ml $^{-1}$ in $50 \mathrm{~mm}$ Tris $\mathrm{HCl}$ buffer $\mathrm{pH} 7.3$ containing $2 \mathrm{~mm}$ dithiothreitol) were sonicated on ice bed (three times at $10 \mathrm{~s}$ intervals) and centrifuged at $100000 \mathrm{~g}$ for $30 \mathrm{~min}$ $\left(+4^{\circ} \mathrm{C}\right)$. The assay consisted in incubating $25 \mu \mathrm{l}$ of cytosol with excess ${ }^{3} \mathrm{H}$-dUMP ( $1 \mu \mathrm{M}$ final concentration) and $\mathrm{CH}_{2} \mathrm{FH}_{4}(0.62 \mathrm{~mm}$ final concentration) in a total volume of $55 \mu \mathrm{l}$ (in the previous buffer). After $0,10,20$ and $30 \mathrm{~min}$ of incubation at $+37^{\circ} \mathrm{C}$, the reaction was stopped on ice bed. The excess of ${ }^{3} \mathrm{H}$-dUMP was removed by adding $300 \mu \mathrm{l}$ of activated charcoal (15\%) containing $4 \%$ trichloracetic acid (5 min centrifugation at $14000 \mathrm{~g}$, room temperature). The ${ }^{3} \mathrm{H}_{2} \mathrm{O}$ formed during the incubation was then measured in an aliquot of the above supernatant. Results were expressed as fmoles of ${ }^{3} \mathrm{H}_{2} \mathrm{O}$ formed per min per mg of protein, based on the linear regression obtained from the incubation times. Cytosolic proteins were determined by the Bradford colorimetric assay (Protein Assay Reagent, Biorad Laboratories, Germany) with human serum albumin as standard. The sensitivity limit was

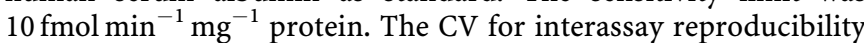
$(N=7)$ was $15 \%$.

\section{Gene polymorphisms}

Thymidylate synthase and MTHFR genetic polymorphisms were analysed on DNA extracted from cell pellets stored in liquid nitrogen.

Determination of $5^{\prime}$ and $3^{\prime}$ TS polymorphisms For the $5^{\prime}$ polymorphism, a fragment containing the 28-bp repeats was amplified (expected fragment size was $220 \mathrm{bp}$ for $2 \mathrm{R}$ and $248 \mathrm{bp}$ for $3 \mathrm{R})$. For the $3^{\prime}$ polymorphism, a fragment containing the $6 \mathrm{bp}$ deletion was amplified (expected fragment sizes were $110 \mathrm{bp}$ for the wild type and $104 \mathrm{bp}$ for the variant allele). In each case, PCR were run on a GeneAmp ${ }^{R}$ PCR system 9700 (Applied Biosystems, Courtabœuf, France) in a $25 \mu \mathrm{l}$ final volume containing $50 \mathrm{ng}$ of genomic DNA, $1 \mathrm{mM} \mathrm{MgCl} 2,2.5 \mu \mathrm{l}$ of buffer $10 \times, 1.25 \mathrm{~mm}$ of dNTPs, $0.15 \mu \mathrm{M}$ of each specific forward and reverse primer and $0.05 \mathrm{U}^{-1} \mathrm{l}^{-1}$ of Taq polymerase Cetus (Perkin Elmer, Courtaboeuf, 
France). After 30 cycles of amplification (denaturation at $94^{\circ} \mathrm{C}$ for $30 \mathrm{~s}$, annealing at $62^{\circ} \mathrm{C}$ for $60 \mathrm{~s}$, and extension at $72^{\circ} \mathrm{C}$ for $90 \mathrm{~s}$ ), amplification products were electrophoresed on acrylamide gel at $8 \%$. For $5^{\prime}$ polymorphism, products of $220 \mathrm{bp}(2 \mathrm{R} / 2 \mathrm{R}), 248 \mathrm{bp}(3 \mathrm{R} /$ $3 R)$ or both $(2 R / 3 R)$ were observed. For $3^{\prime}$ polymorphism, products of $110 \mathrm{bp}(6 \mathrm{bp} / 6 \mathrm{bp}), 104 \mathrm{bp}(0 \mathrm{bp} / 0 \mathrm{bp})$ or both $(6 \mathrm{bp} /$ $0 \mathrm{bp}$ ) were observed.

Determination of MTHFR polymorphisms The C677T (Ala $\rightarrow$ Val) and A1298C (Glu $\rightarrow$ Ala) variants were analysed simultaneously by means of melting curve analyses on LightCycler (Roche), based on the fluorescence resonance energy transfer (FRET) principle (see Figure 2 for a typical example of analysis). We used a method derived from that initially described by Nakamura et al (2002). A duplex PCR amplification was first run in $20 \mu \mathrm{l}$ final volume containing $80 \mathrm{ng}$ genomic DNA $(2 \mu \mathrm{l}), 2 \mu \mathrm{l}$ of ready-to-use Hotstart PCR mixture (LightCycler Faststart DNA Master Hybridization Probes kit, Roche Diagnostic, France), $3 \mathrm{mM} \mathrm{MgCl}_{2}, 0.2 \mu \mathrm{M}$ of each primer, $0.2 \mu \mathrm{M}$ of each specific anchor fluorescein-labelled probe, and $0.4 \mu \mathrm{m}$ of each specific wt variant (C 677 or A 1298 LC-redlabelled probe), in PCR grade water. After DNA denaturation and enzyme activation $\left(8 \mathrm{~min}\right.$ at $\left.95^{\circ} \mathrm{C}\right)$, DNA was amplified for 45 cycles $\left(15 \mathrm{~s}\right.$ at $95^{\circ} \mathrm{C}, 10 \mathrm{~s}$ at $55^{\circ} \mathrm{C}$ and $10 \mathrm{~s}$ at $\left.72^{\circ} \mathrm{C}\right)$. At the end of PCR, melting curves of the DNA/probes complexes synthesised were performed by increasing temperature gradually $\left(0.1^{\circ} \mathrm{C} \mathrm{s}^{-1}\right)$ up to $95^{\circ} \mathrm{C}$. Methylenetetrahydrofolate reductase variant identification was based on the fact that the melting temperature of the DNA/probe complex is lower in the case of DNA/probe T/C mismatch at nucleotide 677 or DNA/probe C/A mismatch at nucleotide 1298. The C677T genotype was monitored at $640 \mathrm{~nm}$ and the melting curve showed a single peak at $64^{\circ} \mathrm{C}$ for $\mathrm{C} / \mathrm{C}$ samples, a single peak at $55^{\circ} \mathrm{C}$ for $\mathrm{T} / \mathrm{T}$ samples, and two peaks for heterozygous cell lines. The A1298C genotype was monitored at $705 \mathrm{~nm}$ and the melting curve showed a single peak at $63^{\circ} \mathrm{C}$ for $\mathrm{A} / \mathrm{A}$ samples, a single peak at $60^{\circ} \mathrm{C}$ for $\mathrm{C} / \mathrm{C}$ samples, and two peaks for heterozygous cell lines. In the event of DNA/probe mismatch, a second PCR (duplex PCR if necessary) was conducted with specific mutated (mut) variants (T 677 or C 1298
LC-red-labelled probes), in order to confirm the presence of the specific analysed mutation.

\section{Data analysis and statistics}

All experiments were performed in triplicate. 5-Fluorouracil $\mathrm{IC}_{50}$ was defined as the concentration causing $50 \%$ growth inhibition as
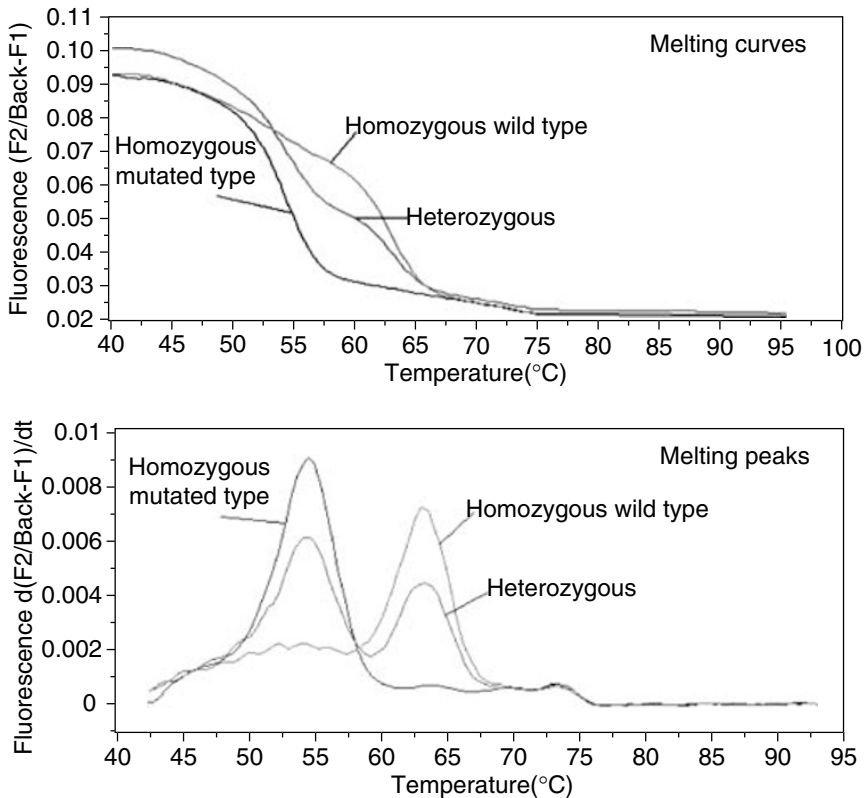

Figure 2 Typical example of melting curves and melting peaks used to genotype C677T MTHFR gene mutation. A wt probe is used. Melting peak temperatures obtained from a derivative of the melting curves are $64^{\circ} \mathrm{C}$ for homozygous wt (CC), $64^{\circ} \mathrm{C}$ and $55^{\circ} \mathrm{C}$ for heterozygous (CT) and $55^{\circ} \mathrm{C}$ for homozygous mut types (TT).

Table 2 Description of TS activity, TS and MTHF polymorphisms

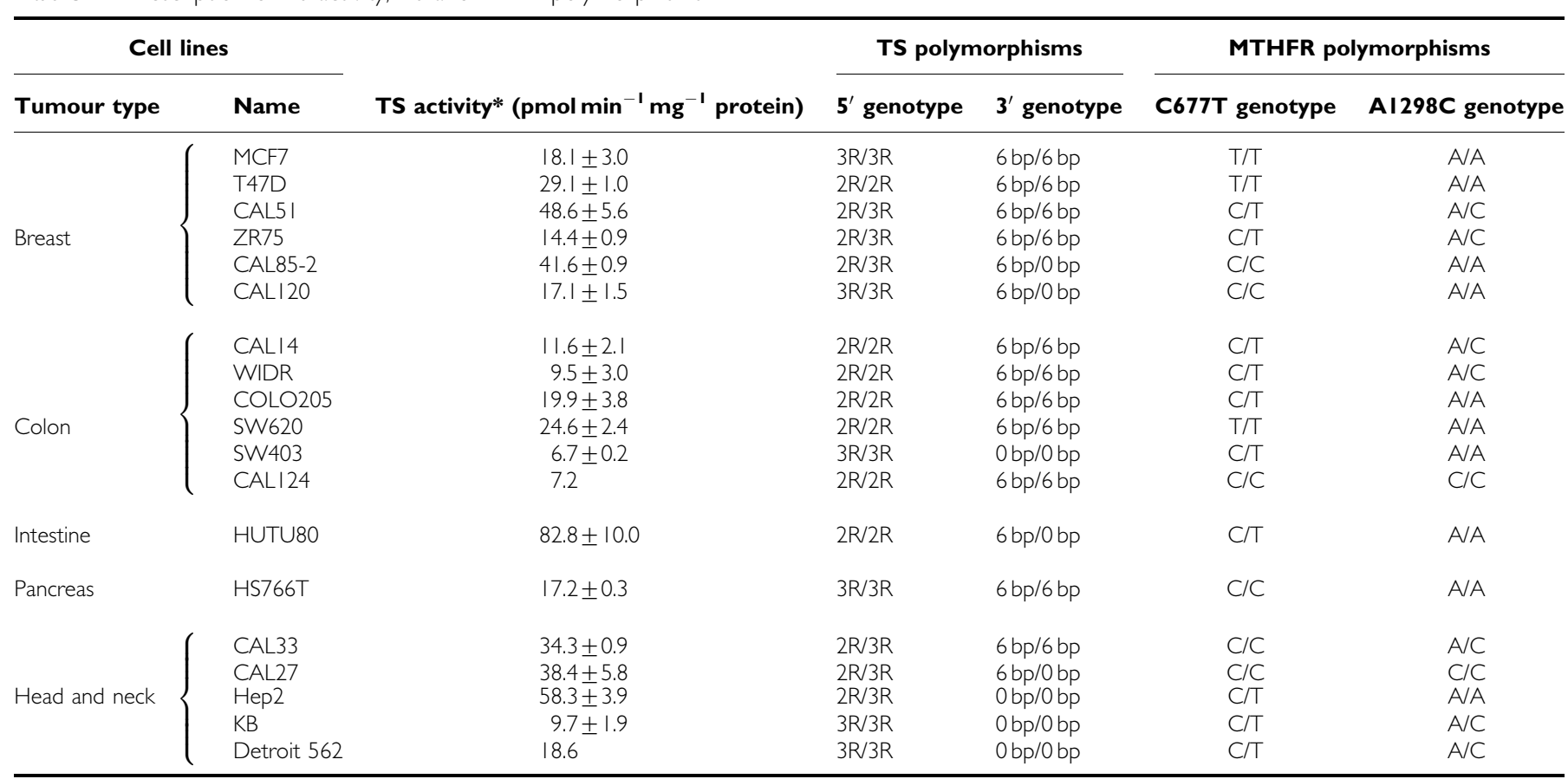

$\mathrm{TS}=$ thymidylate synthase; MTHFR = methylenetetrahydrofolate reductase. 
compared to control cells. In the conditions with FA supplementation, for each tested FA concentration we computed a potentiation factor $(F)$ equal to the $\mathrm{FU} \mathrm{IC}_{50}$ without $\mathrm{FA}$ divided by the $\mathrm{FU} \mathrm{IC}_{50}$ with FA. Optimal FU IC I0 $_{5}$ corresponded to the $\mathrm{IC}_{50}$ obtained in the presence of optimal FA, that is, allowing $90 \%$ of the maximal $F$ value to be reached. Correlations between TS activity and FU $\mathrm{IC}_{50 \text { s }}$ were tested by means of Pearson correlation, after logarithm transformation that allows the Gaussian distribution to be fitted. All other statistics were performed by means of nonparametric tests: Spearman rank correlation, Kruskal-Wallis test, MannWhitney test. For this latter test, mut $v s$ wt comparison was performed by merging homozygous and heterozygous mutated variants $v s$ homozygous wt cell lines. Statistics were performed on SPSS software (Chicago, USA).

\section{RESULTS}

\section{Cell line sensitivity to $\mathrm{FU} \pm \mathrm{FA}$, intracellular reduced folates and TS activity}

Table 1 summarises cell line sensitivity to $\mathrm{FU}$ alone or in combination with optimal FA concentration. In two cell lines (CAL51 and HUTU 80), FU cytotoxicity was not enhanced by FA. The basal intracellular $\mathrm{CH}_{2} \mathrm{FH}_{4}$ concentration was detectable in nine cell lines out of the 19 investigated. Thymidylate synthase activity (Table 2) ranged between 6.7 and $82.8 \mathrm{pmol} \mathrm{min}^{-1} \mathrm{mg}^{-1}$ protein (mean 27). The greater the FU sensitivity, the lower the TS activity $(P=0.078$ and 0.032 , in the absence and presence of optimal FA concentration, respectively). Basal $\mathrm{CH}_{2} \mathrm{FH}_{4}$ was not linked to FU sensitivity.

\section{$5^{\prime}$ and $3^{\prime}$ TS polymorphisms}

Distribution of $5^{\prime}$ TS genotype (Table 2$)$ was $36.8 \% 2 \mathrm{R} / 2 \mathrm{R}(n=7)$, $31.6 \% 2 \mathrm{R} / 3 \mathrm{R}(n=6)$ and $31.6 \% 3 \mathrm{R} / 3 \mathrm{R}(n=6)$. Distribution of $3^{\prime}$ TS genotype (Table 2 ) was $57.9 \% 6 \mathrm{bp} / 6 \mathrm{bp}(n=11), 21.1 \% 6 \mathrm{bp} /$ $0 \mathrm{bp}(n=4)$ and $21.1 \% 0 \mathrm{bp} / 0 \mathrm{bp}(n=4)$. Cell doubling time was not linked to $5^{\prime}$ or $3^{\prime}$ TS genotypes.

Thymidylate synthase activity was significantly different according to $5^{\prime}$ TS genotype, heterozygous cell lines exhibiting significantly higher TS activities than homozygous ones (median 20, 40 and $17 \mathrm{pmol} \mathrm{mn}^{-1} \mathrm{mg}^{-1}$ in $2 \mathrm{R} / 2 \mathrm{R}, 2 \mathrm{R} / 3 \mathrm{R}$ and $3 \mathrm{R} /$ $3 \mathrm{R}$, respectively; Kruskal-Wallis $P=0.050$, Figure $3 \mathrm{~A}$ ). No significant relationship was observed between TS activity and $3^{\prime}$ TS genotype (Kruskal-Wallis $P=0.23$, Figure 3B). Whether in the absence or presence of FA, FU sensitivity was not statistically associated with either $5^{\prime}$ or $3^{\prime}$ TS polymorphism (Figure 4).

\section{C677T and A1298C MTHFR polymorphisms}

Distribution of C677T genotype was 31.6\% C/C $(n=6), 52.6 \% \mathrm{C} / \mathrm{T}$ $(n=10), 15.8 \% \mathrm{~T} / \mathrm{T}(n=3)$ and that of $\mathrm{A} 1298 \mathrm{C}$ was $52.6 \% \mathrm{~A} / \mathrm{A}$ $(n=10), 36.8 \% \mathrm{~A} / \mathrm{C}(n=7)$ and $10.5 \% \mathrm{C} / \mathrm{C}(n=2)$ (Table 2$)$.

From Tables 1 and 2, it appears that basal $\mathrm{CH}_{2} \mathrm{FH}_{4}$ concentrations were not detectable in 5/6 homozygous wt $(\mathrm{C} / \mathrm{C}) 677$ genotype, whereas detectable concentrations were observed in 7/13 mut (T/T and C/T) 677 genotype. Also, basal $\mathrm{CH}_{2} \mathrm{FH}_{4}$ concentrations were below detection limit in $7 / 10$ homozygous wt (A/A) 1298 genotype, in contrast with detectable concentrations observed in 5/9 mut (C/C and A/C) 1298 genotype. The above observations, which did not reach statistical significance, are depicted in Figure 5. Of note, in the three cell lines with homozygous wt genotype for both 677 and 1298 (CAL85-2, CAL120, HS766T), $\mathrm{CH}_{2} \mathrm{FH}_{4}$ was always below the detection limit.

Whether in the absence or presence of FA, FU sensitivity (FU $\mathrm{IC}_{50}$ or optimal (Opt) $\mathrm{FU} \mathrm{IC} 50$ ) was not linked to C677T genotype
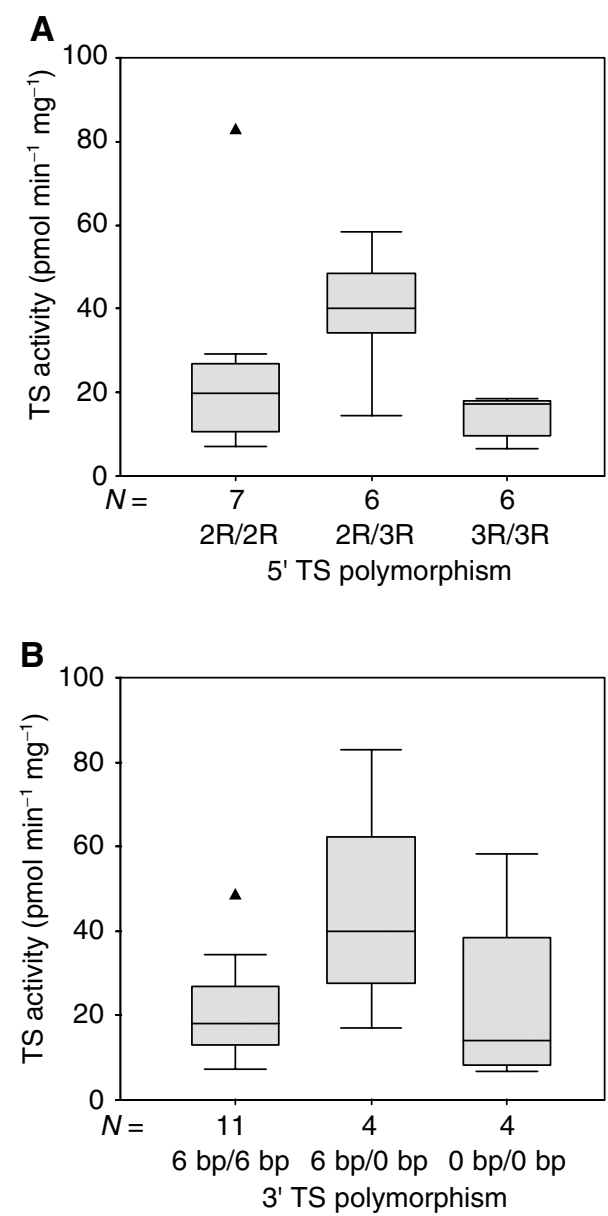

Figure 3 Distribution of TS enzymatic activity according to $5^{\prime}$ TS polymorphism (A) or $3^{\prime}$ TS polymorphism (B). Boxes delimit the first and third quartiles, with the median inside, and bars represent the range of values that fall within 1.5-fold the interquartile range. Triangles ( $\mathbf{\Delta}$ ) represent outliers, defined as individual values greater than 1.5-fold the interquartile range. Kruskall-Wallis $P$-values were 0.050 and 0.23 for $(\mathbf{A})$ and (B), respectively.

(C/C vs $\mathrm{C} / \mathrm{T}$ vs $\mathrm{T} / \mathrm{T}$ : nonsignificant, Figure 6; wt $(\mathrm{C} / \mathrm{C})$ vs mut $(\mathrm{C} / \mathrm{T}+\mathrm{T} / \mathrm{T})$ : nonsignificant $)$. In contrast, $\mathrm{FU}$ efficacy tended to be higher in mutated $\mathrm{A} 1298 \mathrm{C}$ variants $(\mathrm{C} / \mathrm{C}+\mathrm{A} / \mathrm{C})$, both in 'physiological-folate' conditions (Figure 7A) and in the presence of optimal FA concentration (Figure 7B). In 'physiologicalfolate' conditions, $\mathrm{FU} \mathrm{IC} \mathrm{IC}_{50}$ ranged from 0.6 to $25.4 \mu \mathrm{m}$ (median 8.4) in the 10 cell lines exhibiting wt A/A 1298 variant, whereas $\mathrm{IC}_{50}$ were comprised between 0.3 and 7.3 (median 2.9) in the nine cell lines exhibiting mutated A/C or C/C 1298 variants; this difference was very close to statistical significance (Mann-Whitney, $P=0.055$ ). A similar pattern of distribution, although less significant (Mann-Whitney, $P=0.085$ ), was observed for Opt FU IC $\mathrm{I}_{50}$, that is in the presence of optimal FA concentrations.

\section{DISCUSSION}

In the context of cancer treatment, pharmacogenetic exploration may result, in the future, in the replacement of tedious and heavy phenotypic explorations either at blood level (pharmacokinetics) or at tumour level (prognostic/predictive markers) by genetic analyses performed on easily obtainable DNA samples from 

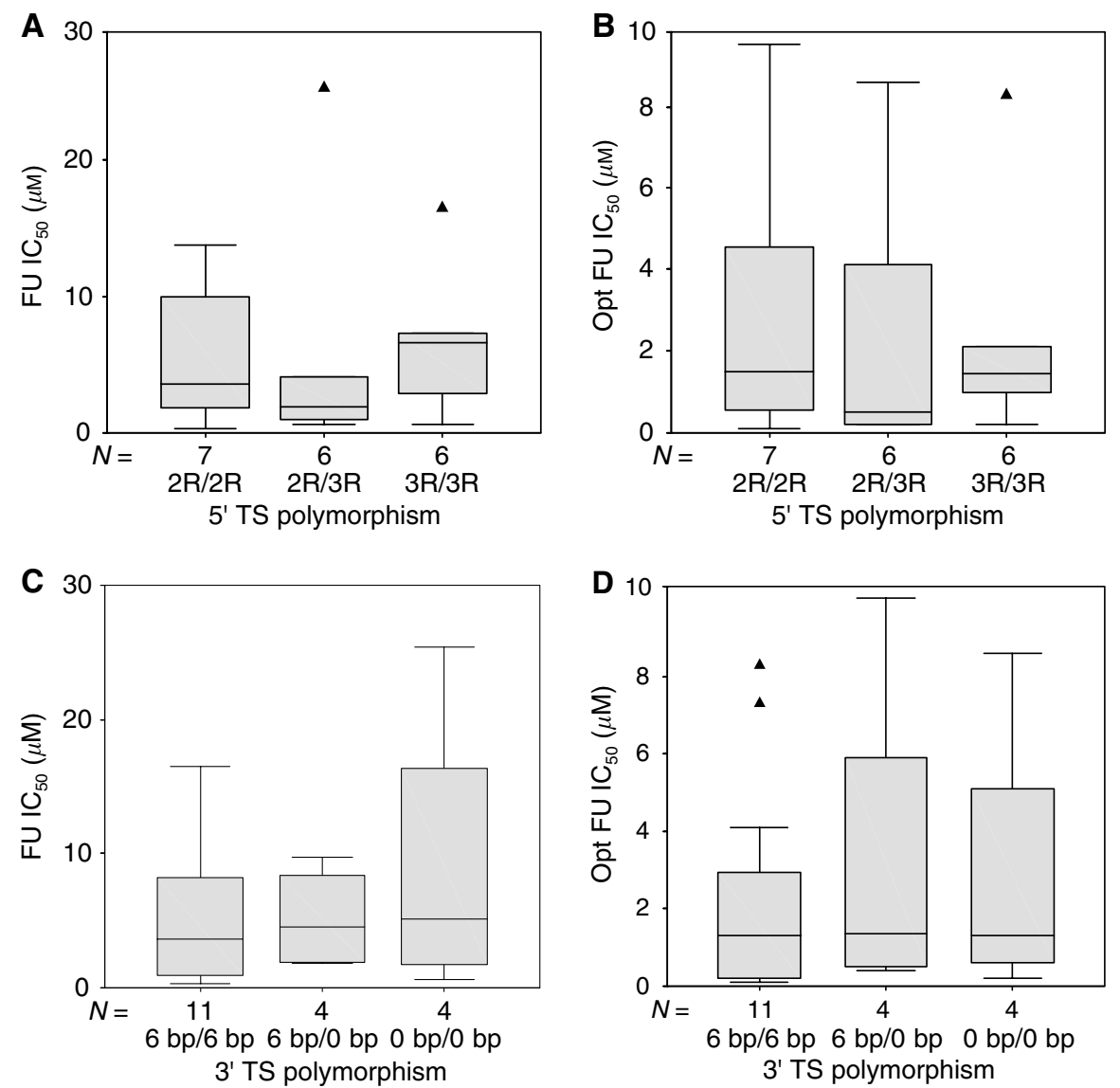

Figure 4 Distribution of FU sensitivity (FU IC 50 in 'physiological-folate' condition, and Opt FU IC 50 in the presence of optimal FA concentration) according to $5^{\prime}$ TS polymorphism $(\mathbf{A}, \mathbf{B})$ or $3^{\prime}$ TS polymorphism $(\mathbf{C}, \mathbf{D})$. Boxes delimit the first and third quartiles, with the median inside, and bars represent the range of values that fall within I.5-fold the interquartile range. Triangles $(\boldsymbol{A})$ represent outliers, defined as individual values greater than I.5-fold the interquartile range. Kruskall-Wallis $P$-values were $0.66,0.81,0.90$ and 0.76 for $(\mathbf{A}),(\mathbf{B}),(\mathbf{C})$ and $(\mathbf{D})$, respectively.

normal cells (blood or oral cavity brushing for instance). The observation that pharmacogenetic status faithfully reflects phenotypic changes at the target level is a prerequisite of clinical pharmacogenetic applications. In fact, from a theoretical point of view, genetic polymorphisms are identical in all tissues. However, the possibility of a clonal selection emerging from a heterozygous subject during the process of carcinogenesis cannot be ruled out. This strengthens the need to examine the impact of cancer-treatment-related gene polymorphisms at the tumoral target itself.

The aim of the present study was thus to analyse the impact at tumoral target level of polymorphisms of two major genes related to DNA synthesis, namely TS and MTHFR polymorphisms, which may influence FU cytotoxicity. To our knowledge, the present experimental study is the first one designed for this purpose. Moreover, the present model was specially controlled for reduced folate status (folate-free medium supplemented with physiological-compatible $\mathrm{CH}_{2} \mathrm{FH}_{4}$ concentrations) and experiments were conducted both in the absence and presence of optimal FA concentrations, in order to mimic the two opposite situations regarding FA supplementation in FU-based treated patients. To this end, we closely explored a panel of 19 cancer cell lines expressing spontaneous FU sensitivity and covering the major fluoropyrimidine-treated localisations (digestive tract, breast, head and neck). The $5^{\prime}$ TS and C677T MTHFR genotype frequencies were in the range of those reported in Caucasian populations (Marsh et al, 1999; Ueland et al, 2001), strengthening the relevance of the present model. The $3^{\prime}$ TS and A1298C MTHFR polymorphisms have been less extensively studied in Caucasian populations, thus frequency comparisons with published data were difficult to perform. The chosen experimental approach did not allow allelotype analyses to be performed, since such analyses require large population studies.

Up to now, clinical studies investigating the influence of $5^{\prime} \mathrm{TS}$ gene polymorphism on TS mRNA or protein level have given rather contrasting results. A retrospective study conducted on 52 colorectal tumour specimens reported that triple repeat homozygous (3R/3R) exhibit 3.6-fold higher TS mRNA levels as compared to double repeat homozygous (2R/2R) (Pullarkat et al, 2001). Another study conducted on 133 cancer biopsies (mostly colorectal cancer) showed no difference in TS mRNA level according to $5^{\prime}$ TS genotype, but demonstrated higher TS protein concentration in $3 \mathrm{R} / 3 \mathrm{R}$ as compared to $2 \mathrm{R} / 2 \mathrm{R}$ (Kawakami et al, $2001 \mathrm{~b}$ ). One of the major findings of the present study is that TS enzymatic activity is significantly influenced by the $5^{\prime} \mathrm{TS}$ genotype. This result is somewhat surprising since TS activity was significantly higher in $2 \mathrm{R} / 3 \mathrm{R}$ heterozygous cell lines (Table 2, Figure 3A). However, superimposable conclusions were drawn from the only available data on the link between TS activity and TS polymorphism, which we recently published on colorectal cancer patients (Etienne et al, 2002). Mandola et al (2003) recently described an additional $\mathrm{G} \rightarrow \mathrm{C}$ SNP within the second 

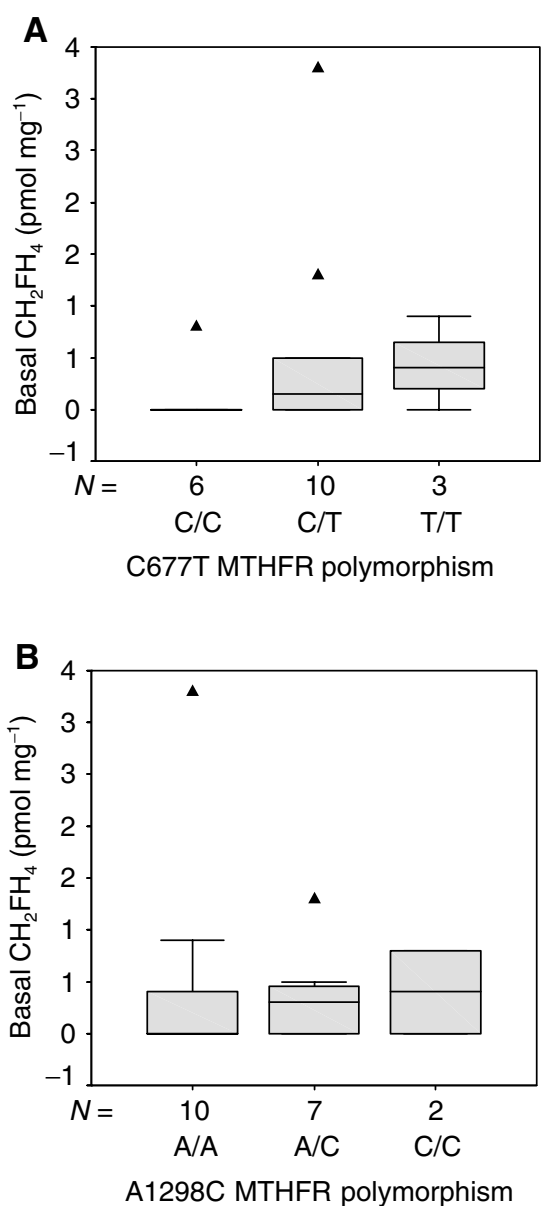

Figure 5 Distribution of basal $\mathrm{CH}_{2} \mathrm{FH}_{4}$ concentration according to C677T MTHFR polymorphism (A) or A I298C MTHFR polymorphism (B). Boxes delimit the first and third quartiles, with the median inside, and bars represent the range of values that fall within 1.5 -fold the interquartile range. Triangles $(\mathbf{\Delta})$ represent outliers, defined as individual values greater than I.5-fold the interquartile range. Kruskall-Wallis $P$-values were 0.36 and 0.74 for $(\mathbf{A})$ and $(\mathbf{B})$, respectively.

repeat of the triple tandem that may influence the transcriptional activity of the gene. Such an additional polymorphism in the $5^{\prime}$ regulatory region with functional consequences on transcriptional activity may complicate the links between TS activity and tandem repeat polymorphisms. This could explain the present unexpected data with a high TS activity in $2 \mathrm{R} / 3 \mathrm{R}$ cell lines. In contrast to $5^{\prime}$ TS genotype, the present experimental data do not support a significant influence of $3^{\prime}$ TS genotype on TS enzymatic activity.

Importantly, the present experimental model was powerful enough to demonstrate the well-established relationship between FU sensitivity and low TS expression (Beck et al, 1994; Peters et al, 2002), herein evaluated as enzymatic activity. In contrast, whether in the absence or presence of FA, FU sensitivity was not statistically associated with either $5^{\prime}$ or $3^{\prime}$ TS polymorphism (Figure 4). The absence of impact of $5^{\prime}$ TS genotype on FU sensibility closely agrees with our previous prospective clinical study (Etienne et al, 2002), reporting identical response rates between $2 \mathrm{R} / 2 \mathrm{R}, 2 \mathrm{R} / 3 \mathrm{R}$ and $3 \mathrm{R} / 3 \mathrm{R}$ patients (genotype analysed on liver metastasis) in 88 patients receiving FU-FA chemotherapy. However, the present results are not in line with other recent clinical studies, most of which were conducted on rather small sets of colorectal cancer patients. Higher response rates were thus
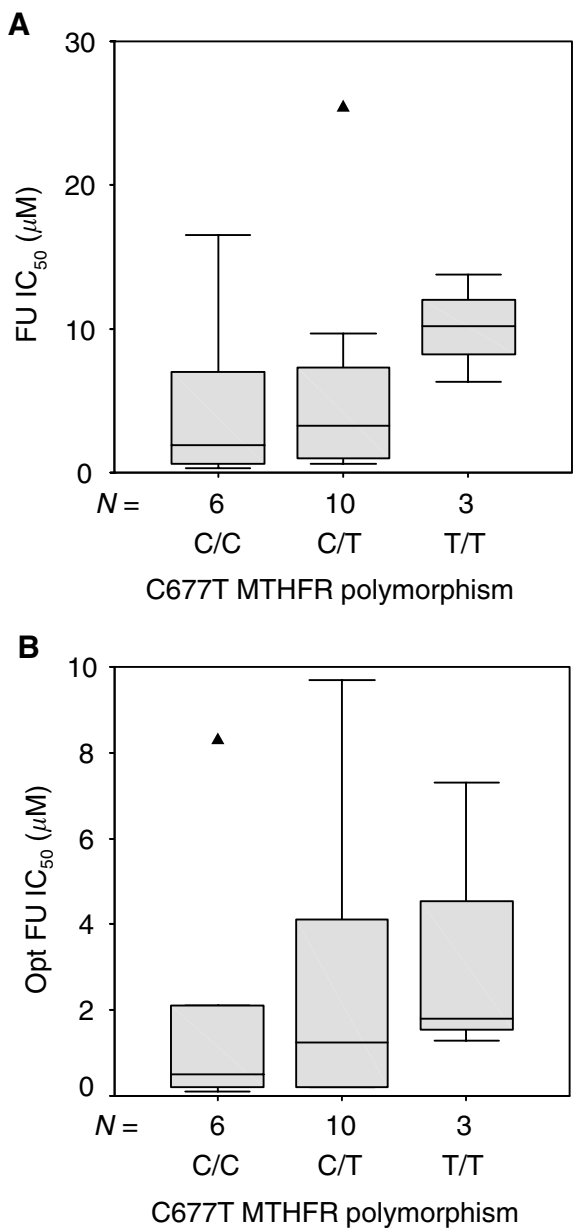

Figure 6 Distribution of $F U I_{50}$ ('physiological-folate' condition (A)) and Opt FU $\mathrm{IC}_{50}$ (in the presence of optimal FA concentration (B)) according to C677T MTHFR polymorphism. Boxes delimit the first and third quartiles, with the median inside, and bars represent the range of values that fall within 1.5-fold the interquartile range. Triangles $(\boldsymbol{\Lambda})$ represent outliers, defined as individual values greater than 1.5 -fold the interquartile range. Kruskall-Wallis $P$-values were 0.20 and 0.45 for $(\mathbf{A})$ and (B), respectively.

reported in $2 \mathrm{R} / 2 \mathrm{R}$ patients by Pullarkat et al (2001) in 50 patients receiving protracted FU infusion and by Park et al (2002) in 24 capecitabine-treated patients. Also, lower downstaging was demonstrated in 3R/3R tumours by Villafranca et al (2001) on 66 rectal cancer patients receiving FU-based chemoradiotherapy protocols. A significant shorter survival rate in $3 R / 3 R$ patients receiving FU-based adjuvant chemotherapy was demonstrated by Iacopetta et al (2001). The value of $5^{\prime}$ TS genotype for predicting fluoropyrimidine responsiveness and its use as a surrogate of TS measurement at the target level is still far from being clearly established, and requires additional large-scale prospective clinical studies including the recently reported $\mathrm{G} \rightarrow \mathrm{C}$ SNP within the triple tandem repeat (Kawakami and Watanabe, 2003; Mandola et al., 2003).

Methylenetetrahydrofolate reductase is a key enzyme of the folate metabolic pathway (Figure 1). Two SNPs (C677T and A1298C) associated with altered phenotypes have been described for this enzyme (Frosst et al, 1995; Weisberg et al, 1998). The mutated forms of these variants (i.e. 677TT and 1298CC) exhibit significantly lower enzymatic activity, and should theoretically lead to an accumulation of intracellular $\mathrm{CH}_{2} \mathrm{FH}_{4}$ concentrations as compared to wt forms. Consequently, C677T and A1298C 

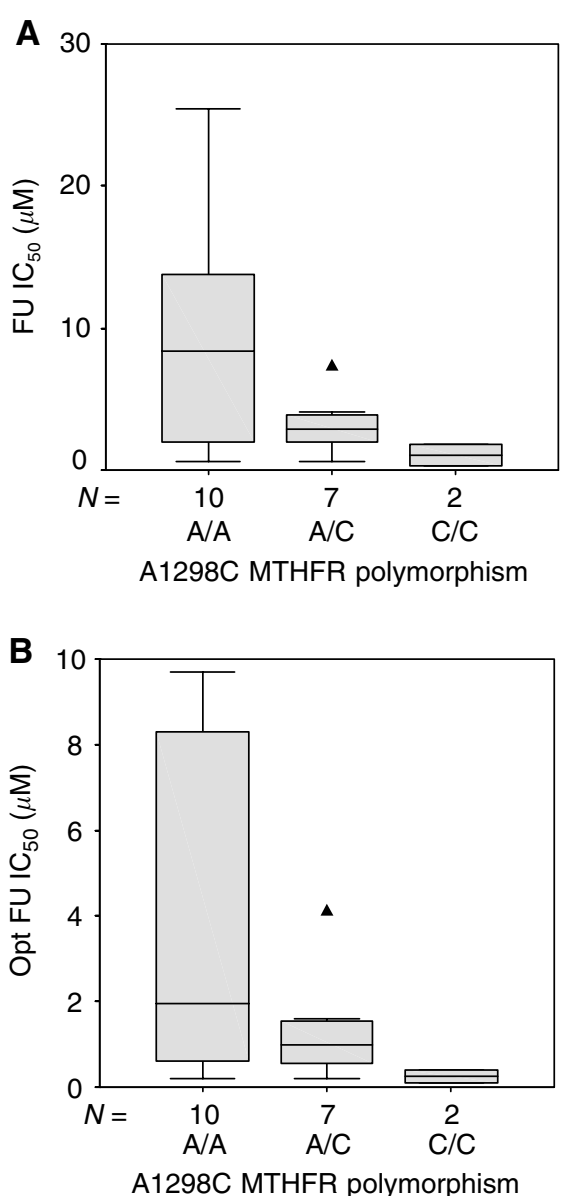

Figure 7 Distribution of $F U \mathrm{IC}_{50}$ ('physiological-folate' condition $(\mathbf{A})$ ) and Opt FU $\mathrm{IC}_{50}$ (in the presence of optimal FA concentration (B) according to AI298C MTHFR polymorphism. Boxes delimit the first and third quartiles, with the median inside, and bars represent the range of values that fall within 1.5-fold the interquartile range. Triangles $(\boldsymbol{\Delta})$ represent outliers, defined as individual values greater than 1.5-fold the interquartile range. Kruskall-Wallis $P$-values were 0.086 and 0.1 I for $(\mathbf{A})$ and $(\mathbf{B})$, respectively.

\section{REFERENCES}

Beck A, Etienne MC, Chéradame S, Fischel JL, Formento P, Renée N, Milano G (1994) A role for dihydropyrimidine dehydrogenase and thymidylate synthase in tumour sensitivity to fluorouracil. Eur J Cancer 30: $1517-1522$

Bunni M, Doig MT, Donato H, Kesavan V, Priest D (1988) Role of methylenetetrahydrofolate depletion in methotrexate-mediated intracellular thymidylate synthesis inhibition in cultured L1210 cells. Cancer Res 48: $3398-3404$

Carmichael J, De Graff WG, Gazdar AF, Minna JD, Mitchelle JB (1987) Evaluation of tetrazolium-based semi-automated colorimetric assay in assessment of chemosensitivity testing. Cancer Res 47: 936-942

Chéradame S, Etienne MC, Chazal M, Guillot T, Fischel JL, Formento P, Milano G (1997a) Relevance of tumoral folylpolyglutamate synthetase and reduced folates for optimal 5-fluorouracil efficacy: experimental data. Eur J Cancer 33: 950-959

Chéradame S, Etienne MC, Formento P, Schneider M., Dassonville O, Demard F, Milano G (1997b) Tumoral-reduced folates and clinical resistance to fluorouracil-based treatment in head and neck cancer patients. J Clin Oncol 15: 2604-2610
MTHFR polymorphisms may influence the pharmacodynamics of fluoropyrimidines since they control the intracellular concentration of the specific reduced folate required for optimal TS inhibition. This hypothesis is supported by preclinical and clinical data (Danenberg and Danenberg, 1978; Houghton et al, 1981; Rustum et al, 1987; Keyomarsi and Moran, 1988; Chéradame et al, 1997a,b) demonstrating the impact of $\mathrm{CH}_{2} \mathrm{FH}_{4}$ intratumoral concentrations on FU cytotoxicity. Recent clinical studies have suggested that MTHFR polymorphisms may be associated with methotrexate pharmacodynamics (Ulrich et al, 2001; Urano et al, 2002). However, no study has so far reported their impact on fluoropyrimidine sensitivity (Wisotzkey et al, 1999). First of all, the present data closely concord with the theoretical impact of C677T and $\mathrm{A} 1298 \mathrm{C}$ polymorphisms on $\mathrm{CH}_{2} \mathrm{FH}_{4}$ intracellular pool: five out of six homozygous wt $\mathrm{C} 677$ variants and seven out of 10 homozygous wt A1298 variants exhibited nondetectable $\mathrm{CH}_{2} \mathrm{FH}_{4}$ concentrations, in contrast to six out of $13 \mathrm{~T} / \mathrm{T}$ or $\mathrm{C} / \mathrm{T} 677$ variants, and four out of nine C/C or A/C 1298 variants (Figure 5, Tables 1 and 2). These data agree with those of Kawakami et al (2001a) who recently reported relationships between MTHFR genotypes and tumoral-reduced folates in gastrointestinal cancer .

The C677T genotype did not significantly influence FU cytotoxicity, whether in the absence or presence of optimal FA supplementation (Figure 6). However, FU sensitivity was related to A1298C MTHFR genotype: homozygous mutated cell lines (C/C) were the more sensitive, homozygous wt $(\mathrm{A} / \mathrm{A})$ were the more resistant, heterozygous cell lines (A/C) exhibiting intermediary sensitivity (Figure 7, Tables 1 and 2). The influence of A1298C MTHFR polymorphism on FU sensitivity was observed irrespective of the absence or presence of optimal FA supplementation. These stimulating results show a trend close to statistical significance $(P=0.055$ and 0.085 in the absence and presence of FA, respectively) and are thus consistent with the initial hypothesis that MTHFR genotypes associated with altered enzymatic activity may be more FU sensitive.

Altogether, it is hoped that the present data will encourage future studies to consider not only TS polymorphisms but also MTHFR polymorphisms as potential predictors of fluoropyrimidine responsiveness and/or toxicity. Both tumoral and constitutional genotype analyses should be taken into account in clinical prospective studies, particularly regarding the design of future FUbased chemotherapy study.

Danenberg PV, Danenberg KD (1978) Effect of 5,10-methylenetetrahydrofolate on the dissociation of 5-fluoro-2'-deoxyuridylate from thymidilate synthase: evidence for an ordered mechanism. Biochemistry 17: 40184024

Doroshow JH, Multhauf P, Leong L, Margolin K, Litchfield T, Akman S, Carr B, Bertrand M, Goldberg D, Blayney D (1990) Prospective randomized comparison of fluorouracil versus fluorouracil and highdose continuous infusion leucovorin calcium for the treatment of advanced measurable colorectal cancer in patients previously unexposed to chemotherapy. J Clin Oncol 8: 491-501

Etienne MC, Chazal M, Laurent-Puig P, Magné N, Rosty C, Formento JL, Francoual M., Formento P, Renée N, Chamorey E et al. (2002) Prognostic value of tumoral thymidylate synthase and p53 in metastatic colorectal cancer patients receiving fluorouracil-based chemotherapy: phenotypic and genotypic analyses. J Clin Oncol 20: 2832-2843

Frosst P, Blom HJ, Milos R, Goyette P, Sheppard CA, Matthews RO, Boers GJ, den Heijer M., Kluitjtmans LA, van den Heuvel LP et al. (1995) A candidate genetic risk factor for vascular disease: a common mutation in methylenetetrahydrofolate reductase. Nat Genet 10: 111-113 
Fumoleau P, Kerbrat P, Romestaing P, Fargeot P, Bremond A, Namer M, Schraub S, Goudier MJ, Mihura J, Monnier A, Clavere P, Serin D, Seffert P, Pourny C, Facchini T., Jacquin JP, Sztermer JF, Datchary J, Ramos R, Luporsi E (2003) Randomized trial comparing six versus three cycles of epirubicin-based adjuvant chemotherapy in premenopausal, nodepositive breast cancer patients: 10-year follow-up results of the French adjuvant study group 01 trial. J Clin Oncol 21: 298-305

Horie N, Aiba H, Oguro K, Hojo H, Takeishi K (1995) Functional analysis and DNA polymorphism of the tandemly repeated sequences in the $5^{\prime}$ terminal regulatory region of the human gene for thymidylate synthase. Cell Struct Funct 20: $191-197$

Houghton JA, Maroda Jr SJ, Phillips JO, Houghton PJ (1981) Biochemical determinants of responsiveness to 5 -fluorouracil and its derivatives in xenografts of human colorectal adeno-carcinomas in mice. Cancer Res 41: $144-149$

Iacopetta B, Grieu F, Joseph D, Elsaleh H (2001) A polymorphism in the enhancer region of the thymidylate synthase promoter influences the survival of colorectal cancer patients with 5-fluorouracil. Br J Cancer 85: $827-830$

Jäger E, Heike M, Bernhard H, Klein O, Bernhard G, Lautz D, Michaelis J, Meyer zum Buschenfelde KH, Knuth A (1996) Weekly high-dose leucovorin versus low-dose leucovorin combined with fluorouracil in advanced colorectal cancer: results of a randomized multicenter trial. J Clin Oncol 14: 2274-2279

Kawakami K, Omura K, Kanehira E, Watanabe G (2001a) Methylenetetrahydrofolate reductase polymorphism is associated with folate pool in gastrointestinal cancer tissue. Anticancer Res 21: 285-289

Kawakami K, Salonga D, Park JM, Danenberg KD, Uetake H, Brabender J, Omura K, Watanabe G, Danenberg PV (2001b) Different lengths of a polymorphic repeat sequence in the thymidylate synthase gene affect translational efficiency but not its gene expression. Clin Cancer Res 7: 4096-4101

Kawakami K, Watanabe G (2003) Single nucleotide polymorphism in the tandem-repeat sequence of thymidylate synthase gene: a candidate for an additional predictor in 5FU-based chemotherapy. Proc ASCO 22: 127 (Abst. 509)

Keyomarsi K, Moran RG (1988) Mechanism of the cytotoxic synergism of fluoropyrimidines and folinic acid in mouse leukemic cells. J Biol Chem 263: $14402-14409$

Mandola MV, Stoehlmacher J, Muller-Weeks S, Cesarone G, Yu MC, Lenz HJ, Ladner RD (2003) A novel single nucleotide polymorphism within the $5^{\prime}$ tandem repeat polymorphism of the thymidylate synthase gene abolishes USF-1 binding and alters transcriptional activity. Cancer Res 63: $2898-2904$

Marsh S, Collie-Duguid ES, Li T, Liu X, McLeod HL (1999) Ethnic variation in the thymidylate synthase enhancer region polymorphism among Caucasian and Asian populations. Genomics 58: 310-312

Marsh S, McKay JA, Cassidy J, McLeod HL (2001) Polymorphism in the thymidylate synthase promoter enhancer region in colorectal cancer. Int J Oncol 19: 383-386

Nakamura S, Aoshima T, Ikeda M, Sekido Y, Shimokata K, Niwa T (2002) Simultaneous detection of methylenetetrahydrofolate reductase gene polymorphisms, C677T and A1298C, by melting curve analysis with Lightcycler. Anal Biochem 306: 340-343

Park DJ, Stoehlmacher J, Zhang W, Tsao-Wei D, Groshen S, Lenz HJ (2002) Thymidylate synthase gene polymorphism predicts response to capecitabine in advanced colorectal cancer. Int I Colorectal Dis 17: 46-49

Peters GJ, Backus HH, Freemantle S, van Triest B, Codacci-Pisanelli G, van der Wilt CL, Smid K, Lunec J, Calvert AH, Marsh S, McLeod HL, Bloemena E, Meijer S, Jansen G, van Groeningen CJ, Pinedo HM (2002) Induction of thymidylate synthase as a 5-fluorouracil resistance mechanism. Biochim Biophys Acta 1587: 194-205

Petrelli N, Herrera L, Rustum Y, Burke P, Creaven P, Stulc J, Emrich LJ, Mittelman A (1987) A prospective randomized trial of 5-fluorouracil versus 5 -fluorouracil and high-dose leucovorin versus 5 -fluorouracil and methotrexate in previously untreated patients with advanced colorectal carcinoma. J Clin Oncol 5: 1559-1565
Piedbois P, Buyse M, Rustum Y (1992) Modulation of fluorouracil by leucovorin in patients with advanced colorectal cancer: evidence in terms of response rate. J Clin Oncol 10: 896-903

Poon MA, O'Connel MJ, Moertel CG, Wieand HS, Cullinan SA, Everson LK, Krook JE, Mailliard JA, Laurie JA, Tschetter LK (1989) Biochemical modulation of fluorouracil: evidence of significant improvement of survival and quality of life in patients with advanced colorectal carcinoma. J Clin Oncol 7: 1407-1418

Posner MR, Colevas AD, Tishler RB (2000) The role of induction chemotherapy in the curative treatment of squamous cell cancer of the head and neck. Semin Oncol 27: 13-24

Pullarkat ST, Stoehlmacher J, Ghaderi V, Xiong YP, Ingles SA, Sherrod A, Warren R, Tsao-Wei D, Groshen S, Lenz HJ (2001) Thymidylate synthase gene polymorphism determines response and toxicity of 5-FU chemotherapy. Pharmacogenomics 1: 65-70

Rozen R (1996) Molecular genetics of methylenetetrahydrofolate reductase deficiency. J Inherit Metab Dis 19: 589-594

Rustum YM, Trave F, Zakrzewski SF, Petrelli N, Herrera L, Mittelman A Arbuck SG, Creaven PJ (1987) Biochemical and pharmacologic basis for potentiation of 5-fluorouracil action by leucovorin. NCI Monogr 5: 165170

Scott J, Weir D (1994) Folate/vitamin B12 inter-relationships. Essays Biochem 28: $63-72$

Spears C, Gustavsson BG (1988) Methods for thymidylate synthase pharmacodynamics: serial biopsy, free and total TS, FdUMP and dUMP, and $\mathrm{H}_{4}$ Pteglu and $\mathrm{CH}_{2}-\mathrm{H}_{4}$ Pteglu assays. In The Expanding Role of Folates and Fluoropyrimidines in Cancer Chemotherapy, Rustum Y, McGuire JJ (eds) pp 97-104. New York: Plenum Press

Ueland PM, Hustad S, Schneede J, Refsum H, Vollset SE (2001) Biological and clinical implications of the MTHFR C677T polymorphism. Trends Pharmacol Sci 22: 195-201

Ulrich C, Bigler J, Velicer C, Greene E, Farin F, Potter J (2000) Searching expressed sequence tag databases: discovery and confirmation of a common polymorphism in the thymidylate synthase gene. Cancer Epidemiol Biomark Prev 9: 1381-1385

Ulrich CM, Yasui Y, Storb R, Schubert MM, Wagner JL, Bigler J, Ariail KS, Keener CL, Li S, Liu H, Farin FM, Potter JD (2001) Pharmacogenetics of methotrexate: toxicity among marrow transplantation patients varies with the methylenetetrahydrofolate reductase C677T polymorphism. Blood 98: 231 - 234

Urano W, Taniguchi A, Yamanaka H, Tanaka E, Nakajima H, Matsuda Y, Akama H, Kitamura Y, Kamatani N (2002) Polymorphisms in the methylenetetrahydrofolate reductase gene were associated with both the efficacy and the toxicity of methotrexate used for the treatment of rheumatoid arthritis, as evidenced by single locus and haplotype analyses. Pharmacogenetics 12: 183-190

Van der Put NM, Gabreels F, Stevens EM, Smeitink JA, Trijbels FJ, Eskes TK, van den Heuvel LP, Blom HJ (1998) A second common mutation in the methylenetetrahydrofolate reductase gene: an additional risk factor for neural-tube defects? Am J Hum Genet 62: 1044-1051

Villafranca E, Okrushnov Y, Dominguez MA, Garcia-Foncillas J, Azinovic I, Martinez E, Illararamendi JJ, Arias F, Martinez Monge R, Salgado E, Angeletti S, Brugarolas A (2001) Polymorphisms of the repeated sequences in the enhancer region of the thymidylate synthase gene promoter may predict downstaging after preoperative chemoradiation in rectal cancer. J Clin Oncol 19: 1779-1786

Weisberg I, Tran P, Christensen B, Sibani S, Rozen R (1998) A second genetic polymorphism in methylenetetrahydrofolate reductase (MTHFR) associated with decrease enzyme activity. Mol Genet Metab 64: 169-172

Wils J, O'Dwyer P, Labianca R (2001) Adjuvant treatment of colorectal cancer at the turn of the century: European and US perspectives. Ann Oncol 12: 13-22

Wisotzkey JD, Toman J, Bell T, Monk JS, Jones D (1999) MTHFR (C677T) polymorphisms and stage III colon cancer: response to therapy. $\mathrm{Mol}$ Diagn 4: 95-99 